\title{
Stability of various particle-stabilised aluminium alloys foams made by gas injection
}

\author{
K. Heim ${ }^{1,2}$, G. S. Vinod-Kumar ${ }^{2, *}$, F. García-Moreno ${ }^{1,2}$, J. Banhart ${ }^{1,2}$ \\ 1. Technische Universität Berlin, Hardenbergstraße 36, 10623 Berlin, Germany \\ 2. Helmholtz-Zentrum Berlin für Materialien und Energie, Hahn Meitner Platz 1, 14109 Berlin, \\ Germany \\ *now at: SRM Research Institute, SRM University, Kattankulathur, 603203, India \\ mail: korbinian.heim@helmholtz-berlin.de, Tel.: +49 30314 29230, Fax: +49 30806243059
}

\begin{abstract}
Aluminium alloy foams are created by injecting air into liquid alloys containing non-metallic particles. In addition to an alloy containing the usual SiC particles, other types of metal/particle composites are studied, which are created by in-situ reactions in the melts: two fluoride salts react and form $\mathrm{TiB}_{2}$ particles, Ca addition or addition of $\mathrm{CuO}$ and $\mathrm{SiO}_{2}$ gives rise to the formation of various oxides and spinel particles. Injecting air into the molten composites through two different steel cannulas leads to the formation of first bubbles and then foam. The entire process is monitored in-situ by X-ray radioscopy. The goal is not only to understand how and what kind of particles stabilise gas injected foams better, but also to reduce the fraction of added particles, which could improve mechanical properties, solve recycling issues and reduce production costs. All the observed composites are shown to have the potential to be processed to metallic foam. Melts containing $\mathrm{TiB}_{2}$ particles are found to perform as well as those containing $\mathrm{SiC}$ even at lower volume fractions. Oxidation of alloy melts promoted by $\mathrm{Ca}$ addition gives rise to melts that exhibit good foamability. Melts oxidised by $\mathrm{CuO}$ and $\mathrm{SiO}_{2}$ addition show partial stability. Mg is found to be a required alloying element to create stable foams. Smaller bubbles can be produced using smaller injector needle openings. By reducing bubble size and using new variants of in-situ generated particles, more stable foams can be achieved with a lower number density of stabilising particles.
\end{abstract}

Keywords: Aluminium alloy foams, particle stabilisation, X-ray imaging, oxidation 


\section{Introduction}

Aluminium foams are complex cellular materials, which can be engineered from dense metals or alloys in many ways [1]. Their unique properties are increasingly attracting attention and potential use as functional or structural light-weight materials is discussed. Especially metal foams created from the liquid by directly injecting gas into a melt through an orifice and forming bubbles therein can be produced in a cost efficient way [2]. Thereby, the cell size can be controlled by the gas flow rate, the orifice diameter and other parameters [3, 4]. However, only alloys containing ceramic particles, so-called metal matrix composites (MMCs), can be used to create a stable foam [5, 6]. Usually, 10-20 vol.\% of $\mathrm{SiC}$ or $\mathrm{Al}_{2} \mathrm{O}_{3}$ particles of particle sizes up to $15 \mu \mathrm{m}$ are added to $\mathrm{Al}$ alloys such as AlSi9Mg [7-9]. Such MMCs are rather expensive to produce, cause problems during secondary operations (e.g. cutting) and also deteriorate some of the mechanical properties of the foam due to the brittleness of the structure [10]. Moreover, the large amount of ceramic particles embedded in the matrix makes recycling of MMCs very difficult. It has been found that the smaller the particles are, the lower their required volume fraction [11]. Therefore, the problems associated with particle addition could be possibly avoided to a certain degree by stabilising foams with smaller particles. Unfortunately, there is a minimum in size at which particles can be easily suspended in a metallic melt due to their wetting behaviour, surface contaminations and other mixing issues.

In the present work we study alternatives to foam-stabilising $\mathrm{SiC}$ or $\mathrm{Al}_{2} \mathrm{O}_{3}$ particles. Particles are no longer added but created directly in the melt by various methods and vary in size, morphology, wetting behaviour, etc. The intention is not only to expand our knowledge of particle stabilisation mechanisms but also to evaluate the possibilities for producing aluminium foams in which properties are not so much influenced by the stabilising particles. Our approach comprise $\mathrm{TiB}_{2}$ particles created in-situ via a flux-assisted synthesis route and particles generated by oxidising melt constituents by adding certain reactants. The aim is to overcome the problem associated with the admixture of particles by creating particles in-situ with diameters in the sub- $\mu \mathrm{m}$ range [12]. $\mathrm{TiB}_{2}$ particles have already been found to be good foam stabilisers when applying the so-called 'Alporas' foaming process, i.e. foaming by adding the blowing agent $\mathrm{TiH}_{2}$ [13-15], where only $2 \mathrm{vol} \%$ of $\mathrm{TiB}_{2}$ are sufficient for foaming. However, this material was hitherto never successfully used for foaming using gas injection and it is a-priori not clear whether this is possible. Melts are sometimes easier to foam by gas release from blowing agents than by gas injection [16], a phenomenon we wish to study here.

All results of the foaming tests obtained are eventually compared to a well-known foamable composite containing SiC particles to discuss its usability.

\section{Experimental}

\subsection{General set-up}

We study various aluminium alloys containing different types and concentrations of stabilising particles as specified in Sec. 2.2. All composites are produced in an open-atmosphere resistance furnace and are molten in alumina crucibles. As a reference material the well-known foamable composite F3S20S produced by Alcan, Montreal, Canada is used. This material contains 20 vol.\% SiC particles (p), mean particle diameter $10 \mu \mathrm{m}$, embedded in a AlSi9Mg0.6 matrix (called AlSi9Mg0.6/SiC/20p). Here, all compositions of the metallic 
components are given in wt.\%, those of the particles in vol.\%. All chemicals and reactants used in the following are from Sigma Aldrich, St. Louis, USA.

For foaming, all composites are remelted in a furnace and processed into foam by air injection. Two different cannulas (from Robert Helwig GmbH, Berlin, Germany) with a conical tip made of stainless steel with an outlet of $500 \mu \mathrm{m}$ or $200 \mu \mathrm{m}$ outer $\left(d_{o}\right)$ and $200 \mu \mathrm{m}$ or $90 \mu \mathrm{m}$ inner diameter $\left(d_{i}\right)$, respectively, are used, thus ensuring small bubble sizes [17]. A detailed description of the setup and procedure can be found elsewhere [3]. The temperature of the melt $\left(680^{\circ} \mathrm{C}\right)$ and the overpressure in the cannulas (300 mbar) are kept constant. All foaming experiments are monitored by in-situ X-ray radioscopy. The system consists of a microfocus X-ray source from Hamamatsu Photonics, Hamamatsu City, Japan, with $5 \mu \mathrm{m}$ spot size operated at $100 \mathrm{kV}$ and $100 \mu \mathrm{A}$ and a panel detector with $50 \mu \mathrm{m}$ pixel size, also from Hamamatsu. $4 \times 4$ pixel binning is applied to increase time resolution to 5 fps, i.e. 200 ms image repetition time [18]. Images are subsequently processed using the software "ImageJ”.

In Table 1, all composites (\#1-14) prepared in-house are listed. They are compared to the commercially available standard composite AlSi9Mg0.6/SiC/20p (\#0). The materials used for foaming via gas injection vary in particle concentration and production method, namely in-situ synthesis (\#1-3) or oxidation of the melt (\#4-14, three different variants). In the following, a detailed description of composite production is presented.

\subsection{Composite production}

In a first step, composites based on Al99.5, AlSi9 and AlSi9Mg0.6 melts and containing 6 vol.\% TiB 2 particles (mean particle diameter is $0.5 \mu \mathrm{m}-3 \mu \mathrm{m}$ ) are prepared via a flux-assisted synthesis route using two reactant salts: $\mathrm{KBF}_{4}$ and $\mathrm{K}_{2} \mathrm{TiF}_{6}[19]$. Exothermal reactions between the two components take place according to the following sequence (s = solid, $\mathrm{l}=$ liquid) $[20]$ :

$$
\begin{aligned}
& 3 \mathrm{~K}_{2} \mathrm{TiF}_{6}(\mathrm{~s})+13 \mathrm{Al}(\mathrm{l}) \rightarrow 3 \mathrm{TiAl}_{3}(\mathrm{~s})+3 \mathrm{KAlF}_{4}(\mathrm{~s} / \mathrm{l})+\mathrm{K}_{3} \mathrm{AlF}_{6}(\mathrm{~s} / \mathrm{l}), \\
& 2 \mathrm{KBF}_{4}(\mathrm{~s})+3 \mathrm{Al}(\mathrm{l}) \rightarrow \mathrm{AlB}_{2}(\mathrm{l})+2 \mathrm{KAlF}_{4}(\mathrm{~s} / \mathrm{l}), \\
& \mathrm{AlB}_{2}(\mathrm{l})+\mathrm{TiAl}_{3}(\mathrm{~s}) \rightarrow \mathrm{TiB}_{2}(\mathrm{~s})+4 \mathrm{Al}(\mathrm{l})
\end{aligned}
$$

After reaction and intermediate stirring, the slag containing $\mathrm{KAlF}_{4}$ and $\mathrm{K}_{3} \mathrm{AlF}_{6}$ is removed and the molten composite is cast into a graphite mould. The resulting composites are listed in Table 1 (entries 1-3).

Knowing that the already mentioned 'Alporas' process is suitable to produce stable foams from a liquid alloy, the same melt pre-treatments are applied to prepare precursors for the gas injection method: Calcium particles of $0.2 \mathrm{~mm}-3 \mathrm{~mm}$ mesh size are added into the stirring vortex of the melt at $700{ }^{\circ} \mathrm{C}$ and are stirred thereafter for $10 \mathrm{~min}$ at $1000 \mathrm{rpm}$ using a graphite impeller. Eventually, the melt is poured into a mould and solidified there [14]. Due to the high oxidation affinity of $\mathrm{Ca}$, fine solid particles of $\mathrm{CaO}$ or $\mathrm{CaAl}_{2} \mathrm{O}_{4}$ are formed during stirring in the presence of air and dispersed during mixing [14, 21]. Similarly, $\mathrm{Al}_{2} \mathrm{O}_{3}$ and $\mathrm{MgO}$ can be created depending on the alloy used (Al-Si-Mg). As a matrix material, Al99.5, AlSi9, AlSi9Mg0.6 are used, see Table 1, entries \#4-6.

Mg additions are often found to improve foaming by supporting wetting of added powders and reactant salts [22]. Therefore, we restrict our study on AlSi9Mg0.6 alloys in the following experiments. 
In additional experiments, reactive oxidants are used to form particles in-situ and to prepare composites for foaming. (i) $\mathrm{CuO}$ or (ii) $\mathrm{SiO}_{2}$ (quartz) are used. In both cases, the oxidants are preheated at $300{ }^{\circ} \mathrm{C}$ for $3 \mathrm{~h}$ to remove moisture and to support wetting by the molten alloy AlSi9Mg0.6. The oxidants are slowly immersed into the molten alloy held at $700{ }^{\circ} \mathrm{C}$ through the vortex created by stirring at $1000 \mathrm{rpm}$ [23]. As particle addition is still accompanied by poor wetting and entrainment of gas during stirring, subsequent degassing and particle homogenisation is performed applying ultrasonic vibrations generated by a device (DPC I series, Dukane Corporation, St. Charles, USA), consisting of an ultrasound generator, a transducer and a titanium horn that transmits the vibrations into the melt [22, 24]. The generator operates at $1.7 \mathrm{~kW}$ power and a frequency of $20 \mathrm{kHz}$. The horn is dipped $5 \mathrm{~mm}$ deep into the melt and is kept there for $5 \mathrm{~min}$ until the equilibrium temperature has been reached, after which ultrasound is applied for $2 \mathrm{~min}$. The conditioned melt is then held for either $1 \mathrm{~h}$ or $10 \mathrm{~h}$ at $700^{\circ} \mathrm{C}$.

The oxidants used react with the melt in different ways [25]:

(i) For 1.25, 2.5 and 3.75 vol.\% $\mathrm{CuO}$ (particle size $<10 \mu \mathrm{m}$ ) and the reference alloy AlSi9Mg0.6 the following reactions take place:

$$
\begin{aligned}
& 2 \mathrm{Al}(\mathrm{l})+\mathrm{Mg}(\mathrm{l})+4 \mathrm{CuO}(\mathrm{s}) \rightarrow \mathrm{MgAl}_{2} \mathrm{O}_{4}(\mathrm{~s})+4 \mathrm{Cu}(\mathrm{l}), \\
& 2 \mathrm{Al}(\mathrm{l})+3 \mathrm{CuO}(\mathrm{s}) \rightarrow \mathrm{Al}_{2} \mathrm{O}_{3}(\mathrm{~s})+3 \mathrm{Cu}(\mathrm{l}), \\
& \mathrm{Mg}(\mathrm{l})+\mathrm{CuO}(\mathrm{s}) \rightarrow \mathrm{MgO}(\mathrm{s})+\mathrm{Cu}(\mathrm{l}) .
\end{aligned}
$$

All reactions can occur independently but in the presence of $\mathrm{Al}, \mathrm{Si}$ and $\mathrm{Mg}$, reaction (4) and the formation of $\mathrm{MgAl}_{2} \mathrm{O}_{4}$ (spinel) is usually dominating [26]. Once the small amount of only $0.6 \mathrm{wt} . \% \mathrm{Mg}$ has been consumed, reaction (5) and the associated formation of $\mathrm{Al}_{2} \mathrm{O}_{3}$ particles become predominant. Reaction (6) is mentioned for the sake of completeness but is not relevant at Mg concentrations $<1 \mathrm{wt} . \%$ at the given temperature [27]. Furthermore, all three reactions lead to an enrichment of the alloy in $\mathrm{Cu}$.

(ii) $\mathrm{SiO}_{2}$ particles smaller than $50 \mu \mathrm{m}$ and volume fractions of 2.5, 5 and 10 vol.\% are used. The following reactions between $\mathrm{SiO}_{2}$ and the molten AlSi9Mg0.6 alloy take place [26, 28]:

$$
\begin{aligned}
& 2 \mathrm{Al}(\mathrm{l})+\mathrm{Mg}(\mathrm{l})+2 \mathrm{SiO}_{2}(\mathrm{~s}) \rightarrow \mathrm{MgAl}_{2} \mathrm{O}_{4}(\mathrm{~s})+2 \mathrm{Si}(\mathrm{l}, \text { in } \mathrm{Al}), \\
& 4 \mathrm{Al}(\mathrm{l})+3 \mathrm{SiO}_{2}(\mathrm{~s}) \rightarrow 2 \mathrm{Al}_{2} \mathrm{O}_{3}(\mathrm{~s})+3 \mathrm{Si}(\mathrm{l}, \text { in } \mathrm{Al}), \\
& 2 \mathrm{Mg}(\mathrm{l})+\mathrm{SiO}_{2}(\mathrm{~s}) \rightarrow 2 \mathrm{MgO}(\mathrm{s})+\mathrm{Si}(\mathrm{l}, \text { in } \mathrm{Mg}), \\
& 2 \mathrm{MgO}(\mathrm{l})+3 \mathrm{SiO}_{2}(\mathrm{~s}) \rightarrow 2 \mathrm{MgAl}_{2} \mathrm{O}_{4}(\mathrm{~s})+3 \mathrm{Si}(\mathrm{l}, \text { in } \mathrm{Al}) .
\end{aligned}
$$

The assumed reactions are similar to those for $\mathrm{CuO}$. The formation of $\mathrm{MgAl}_{2} \mathrm{O}_{4}$ occurs first, reaction (7), followed by reaction (8) after all $\mathrm{Mg}$ has been consumed. The MgO reacted in (9) is only metastable and eventually transforms to $\mathrm{MgAl}_{2} \mathrm{O}_{4}$, see reaction (10) [26]. The details of all composites used are summarised in Table 1, entries 7-9 (CuO) and 10-14 $\left(\mathrm{SiO}_{2}\right)$.

Reaction products, composition and morphology are analysed using light microscopy and a scanning electron microscope (SEM) GEMINI LEO 1530 (Zeiss, Oberkochen, Germany) equipped with an energy dispersive Xray spectroscopy system (EDX, Thermo Fisher). A secondary electron detector perpendicular to the surface, called 'in-lens detector', is used to distinguish between different particles due to its high Z-contrast sensitivity. 


\subsection{Evaluation of foamability}

To discuss the ability of a material to be foamed via the liquid metal route, different terms related to its stability are defined: (I) Liquid foams that have a homogeneous structure and exhibit a narrow bubble size distribution, exhibit only little coalescence ( $<5$ rupture events over $300 \mathrm{~s}$ in the given volume, corresponding to a rupture rate density of $<6.25 \cdot 10^{-4}$ ruptures $\mathrm{s}^{-1} \cdot \mathrm{cm}^{-3}$ ) as detected by X-ray radiography and form a foam column of $>40 \mathrm{~mm}$ in height are called "foamable". (II) In other cases, films can rupture, which gives rise to a coarser pore size distribution especially at the top of the foam, and foam expansion is limited to $\leq 40 \mathrm{~mm}$ height by the weight of the foam. From such a material one can still create foams of a certain height, which is why the material is called "partially foamable". (III) If ascending bubbles collapse immediately after reaching the surface of the melt, loose gas and form a characteristic disordered structure of deformed bubbles and dross that has been characterised as onion-shaped [16], the composite will be called "not foamable". This is shown schematically in Figure 1.

To provide a quantitative value for foam quality for a partially stable foam the quantity $Q$ is defined:

$$
Q=\frac{A_{\text {foam }}}{A_{\text {bubble }}},
$$

where $A_{\text {foam }}$ is the projected area of the foam in its fully expanded state and $A_{\text {bubble }}$ the average bubble area determined by measuring the diameter of 10 typical bubbles by the line intersection method of $\mathrm{X}$-ray radiographies, see Figure 2a,b. Even though the measurement is done on the projection of a 3D object, different results can be compared because the procedure is always the same. A foam can be called more stable the higher $Q$ is, i.e. the more bubbles are present in a given foam volume at the maximum expansion stage.

The (average) relative density of the foams $\rho_{\text {foam }}$ is calculated by measuring the average transmitted X-ray intensity $I_{\text {foam }}$ in the central area of the foam and relating it to the average transmitted intensity $I_{\text {bulk }}$ when the unfoamed melt is placed in the beam and applying Beer-Lambert's attenuation law:

$$
\rho_{\text {foam }}=\frac{\ln \left(I_{\text {foam }} / I_{0}\right)}{\ln \left(I_{\text {bulk }} / I_{0}\right)}
$$

where $I_{0}$ is the incoming beam intensity. The quantities occurring in Eqs. (11) and (12) are explained in Figure 2.

\section{Results}

\subsection{SiC-reinforced composite (reference system, \#0 in Table 1)}

AlSi9Mg0.6 with 20 vol.\% SiC particles (AlSi9Mg0.6/SiC/20p) is known as a well-foamable precursor for the gas injection process [7] and shows excellent foaming behaviour under the present circumstances too, see Figure 3. The Plateau borders (the edge where three films meet) are densely covered by particles. All results for this and all following composites are summarised in Table 2.

\section{2. $\quad$ TiB $_{2}$-reinforced composites (\#1,2,3 in Table 1)}

By comparing foams made from different composites containing $\mathrm{TiB}_{2}$ particles, see Figure 4, the importance of Mg becomes clear, as only AlSi9Mg0.6 reinforced with 6 vol.\% $\mathrm{TiB}_{2}$ (\#3) can be successfully foamed. 
$\mathrm{Al} / \mathrm{TiB}_{2} / 6 \mathrm{p}$ (\#1) and AlSi9/TiB $/ 6 \mathrm{p} \mathrm{( \# 2)} \mathrm{are} \mathrm{found} \mathrm{to} \mathrm{be} \mathrm{"not} \mathrm{foamable"} \mathrm{using} \mathrm{any} \mathrm{of} \mathrm{the} \mathrm{injectors}\left(d_{o}=200 \mu \mathrm{m}\right.$ and $500 \mu \mathrm{m}$ ). The foam structure of AlSi9Mg0.6/TiB $/ 6 \mathrm{p}$ (Figure 4c) is similar to that of AlSi9Mg0.6/SiC/20p (Figure 3a,b) featuring uniform bubble sizes and no notable coalescence during and after foaming as can be confirmed by X-ray radiography (compare Figure 4c,d). Therefore, this composite is called "foamable". Microstructural analysis shows stable thick (lower part of foam) or thin (upper part of foam) Plateau borders and films, see Figure 4a,b), where $\mathrm{TiB}_{2}$ particles (dark) are seen to be globally well distributed but tend to agglomerate locally on a smaller scale. This is confirmed by SEM images, in which single particles of 1-3 $\mu \mathrm{m}$ diameter are seen to show a pronounced clustering tendency leading to the formation of agglomerates up to $200 \mu \mathrm{m}$ in size, compare Figure 5c,d.

\subsection{Composites prepared by Ca addition (\#4,5,6 in Table 1)}

AlSi9Mg0.6/*Ca/1.5p (\#6, asterisk indicates that $\mathrm{Ca}$ is the reactant, not the particle) develops a well expanded foam structure after $15 \mathrm{~s}$ of gas injection, see X-ray radioscopy in Figure 6a. However, if bubble injection continues for another $60 \mathrm{~s}$, this structure cannot be expanded any further. Newly ascending bubbles are spherical and does not collapse immediately, but are not able to push the overlying bubbles upwards in order to further expand the foam. Instead, all bubbles above the black dashed line in Figure 6b appear compressed, which indicates that they have lost gas. The liquid foam shrinks notably and is also too brittle to be further investigated after solidification. Therefore, the composite is classified "partially foamable".

Decreasing the injector diameter $d_{o}$ from $500 \mu \mathrm{m}$ to $200 \mu \mathrm{m}$ does not improve foamability. An increasing amount of $\mathrm{Mg}$ or Ca also does not improve foamability, as the melt becomes too viscous, bubbles do not detach from the cannula or become too big to expand to a proper foam (results not shown). Composites based on Al99.5 (\#4) and AlSi9 (\#5) do not foam (not shown). Figure 6c,d shows the oxide network created by the oxidation process.

\subsection{Oxide and spinel-reinforced composites (\#7-14 in Table 1)}

The alloy AlSi9Mg0.6 is blended with $\mathrm{SiO}_{2}$ or $\mathrm{CuO}$ in various concentrations to produce $\mathrm{Al}_{2} \mathrm{O}_{3} / \mathrm{MgAl}_{2} \mathrm{O}_{4}$ particles (\#7-14). It is found that for both oxidants only ultrasonically pre-treated melts can be foamed, see Figure 7. If no pre-treatment is carried out, a layer of small bubbles caused by poorly wetted $\mathrm{SiO}_{2}$ or $\mathrm{CuO}$ particles during mixing is formed and floats to the top of the melt, see inset in Figure 7b. Bubbles reaching that top layer enriched in particles are hindered and eventually merge to a single big bubble. For the pre-treated melts, foaming is only possible until a certain foam height has been reached, as from that stage on ascending bubbles cannot push the overlying foam upwards and bubbles on the top are compressed. This behaviour is similar to that of composite \#6. However, even after $60 \mathrm{~s}$ of holding no coalescence is observed. For the composites made by $\mathrm{SiO}_{2}$ and $\mathrm{CuO}$ addition to AlSi9Mg0.6 alloy, the minimum amount required to produce a partially stable foam is found to be 5 vol.\% (\#12) and 2.5 vol.\% (\#8) respectively, see Figure 7. By increasing the amount of particles beyond this limit or by keeping melts for longer or shorter holding times no significant improvement can be achieved, compare Table 2 .

In Figure 8, the influence of the dimensions of the injector orifice ( $d_{o}=500$ or $\left.200 \mu \mathrm{m}\right)$ on the foaming behaviour of AlSi9Mg0.6/*CuO/3.75p (\#9, $\mathrm{CuO}$ is the reactant) can be seen. It is found that a decrease of the 
cannula orifice size leads to a reduction of bubble size from $7.5 \pm 1 \mathrm{~mm}$ to $3.2 \pm 0.5 \mathrm{~mm}$ (average of 10 individual bubbles), while the number of bubble layers is increased from approximately 5 to 10 . The maximum height of the foam remains similar and is around $40 \mathrm{~mm}$ in both cases. For composites made by $\mathrm{SiO}_{2}$ addition (\#12-14), the observations are similar, which is why they are not shown here.

In Figure 9a, large agglomerates of $\mathrm{CuO}$ in the unfoamed precursor AlSi9Mg0.6/*CuO/2.5p not pre-treated by ultrasound can be seen. In Figure 9b,c, a cell wall in a foam made from the corresponding ultrasonically pretreated composite is shown. Dark spots in Figure 9c can be identified by SEM and EDX, see Figure 9d,e and Figure 9f-h, respectively, as mainly $\mathrm{MgAl}_{2} \mathrm{O}_{4}$ and Al-Mg-O metal transition phase (point 2 and 3) by calculating the $\mathrm{Al} / \mathrm{Mg}$ ratio, which is equal 2 for stoichiometric spinel (the oxygen composition given by EDX is not reliable) and $>2$ for Al-Mg-O transition phases [12]. The identity of $\mathrm{MgAl}_{2} \mathrm{O}_{4}$ can also be confirmed by the typical octahedral crystallite morphology as found in Figure 9e, point 3. The size of individual spinel particles is $0.5-2 \mu \mathrm{m}$, but as such particles tend to agglomerate their effective size is increased to $2-5 \mu \mathrm{m}$, see Figure 9e. Furthermore, $\mathrm{Cu}$ and $\mathrm{CuAl}_{2}$ originating from the reactant $\mathrm{CuO}$ is still found everywhere.

For the reactant $\mathrm{SiO}_{2}$, the behaviour is similar. Figure 10a shows an almost unreacted $\mathrm{SiO}_{2}$ particle found in the melt not conditioned by ultrasound. If ultrasound pre-treatment is performed stable cell walls are obtained, see Figure 10b,c. The nature of the suspected oxides (dark spots) in Figure 10c is determined by EDX (Figure 10f,g) as being $\mathrm{MgAl}_{2} \mathrm{O}_{4}$ and $\mathrm{Al}-\mathrm{Mg}-\mathrm{O}$ transition phase (point 1), see Figure 10d,e. The size of the particles ranges from $1 \mu \mathrm{m}$ to $2 \mu \mathrm{m}$, whereas their agglomerates combine to clusters of $5 \mu \mathrm{m}$ to $10 \mu \mathrm{m}$ size. Blocky areas (point 2) are remnants of $\mathrm{SiO}_{2}$ or other Si-containing phases (Mg-Al-Si-O, Al-Mg-Si-O, etc.) in the base alloy. All values of the quantitative elemental analyses are listed in Table 3.

\section{Discussion}

Comparison of foams obtained from composites containing different types of particles shows that the composite AlSi9Mg0.6/TiB $2 / 6 \mathrm{p}$ (\#3) allows one to obtain equally stable foams as the conventional composite AlSi9Mg0.6/SiC/20p (\#0), compare Figures 3 and 4. Foam stabilised by $\mathrm{TiB}_{2}$ remains stable for heights $>40 \mathrm{~mm}$ and little film rupture is observed $\left(<6.25 \cdot 10^{-4}\right.$ ruptures $\left.\mathrm{s}^{-1} \cdot \mathrm{cm}^{-3}\right)$. If the $\mathrm{TiB}_{2}$ particle fraction is reduced to below a level of 6 vol.\% no or only partially stable foams are obtained. This coincides with studies on melts containing $\mathrm{SiC}$ particles, which are characterised by an analogous, although higher particle fraction too [5, 7, 11, 29, 30].

Furthermore, it is found that $\mathrm{Mg}$ in composite \#3 is required for successful foaming as foams based on $\mathrm{Al} / \mathrm{TiB}_{2} / 6 \mathrm{p}$ (\#1) and $\mathrm{AlSi} / \mathrm{TiB}_{2} / 6 \mathrm{p}$ (\#2) composites are not stable, see Figure 4. This behaviour can be attributed to the increased oxidation rate caused by $\mathrm{Mg}$, which is required for stabilisation [31]. A supporting result was obtained by studying individual metallic films and foams containing $\mathrm{SiC}$, where it was found that the thick immobile oxide skin required to stabilise both films and foams can only be formed if the alloy contains $\mathrm{Mg}$ [3]. The same mechanism can be assumed to be effective for $\mathrm{TiB}_{2}$ foams as well. This interpretation implies that beside particles, the presence of both oxygen in the injected gas and $\mathrm{Mg}$ in the alloy is essential for foam stability and is therefore used in all further studies. This and the requirements discussed in the following that are necessary for obtaining stable foams by gas injection are schematically summarised in Figure 11. 
Even though Mg is necessary to form a partially stable foam from the composite thickened by Ca addition, a too pronounced increase in $\mathrm{Mg}$ and Ca levels does not improve foamability because addition of $>1 \mathrm{wt}$.\% $\mathrm{Mg}$ or $>2$ wt.\% Ca leads to very viscous melts due to the creation of a high fraction of oxides (results not shown). This then hinders bubbles to detach from the orifice, giving rise to big bubbles (>10 mm) and to poor foam. Our composites created by adding oxidants $\left(\mathrm{SiO}_{2}\right.$ and $\left.\mathrm{CuO}\right)$ exhibit similar issues. Particles tend to agglomerate, attach to bubbles and form a top layer that appears dense in the X-ray images, see Figure 7b, and might be rather viscous. Only very big bubbles are created and no foam expansion is possible if no pre-treatment is performed. Only after conditioning the melt by ultrasonic pre-treatment this blocking top layer vanishes, particles are distributed more homogenously and partially stable foams are created. However, none of the melts containing such oxides are well foamable. Only a maximum foam height $<40 \mathrm{~mm}$ is achieved, after which further expansion is hindered after newly arriving bubbles compress the existing foam and gas is lost. One reason for this might be that small particles $(0.5-2 \mu \mathrm{m})$ created in-situ still agglomerate too severely and are not as effective as if they were homogenously distributed within the foam [5, 11, 32]. Thereby, thin cell walls are only formed locally due to the inhomogeneous particle distribution and ruptures and gas loss occurs. Particle agglomeration also reduces the concentration of particles that are effective in stabilising the foam and reduces it to below the necessary minimum [5, 7, 29]. Therefore, a proper distribution of particles approaching the sub- $\mu m$ scale is a prerequisite to create "good” foams.

A general definition of a "good" foam is not available, but Eq. (11) at least allows for a first classification of foams, i.e. of foamability. In this respect the bubble size also plays a decisive role. As Figure 8 shows the number of bubble layers inside a liquid foam can be increased by a factor of two if the bubble size is halved, see also value $Q$ in Table 2. Thus one can state that it is favourable to create smaller bubbles if one is aiming at producing "good” foams. A similar conclusion was already drawn for individual aluminium films representing foam cell walls [33].

It can be stated that in-situ created particles are potential alternatives to known composites containing e.g. SiC or $\mathrm{Al}_{2} \mathrm{O}_{3}$ particles that are added to a melt. Especially $\mathrm{TiB}_{2}$-containing composites are found to be very well foamable by gas injection, which has previously been verified only for foam blown by $\mathrm{TiH}_{2}$ addition. Even a smaller minimum particle fraction (6 vol.\%) is required as for commonly used particles ( 10 vol.\% for SiC) [2, 7, 29]. To further reduce the necessary particle fraction, small sub- $\mu$ m sized particles such as $\mathrm{Al}_{2} \mathrm{O}_{3}$ and $\mathrm{MgAl}_{2} \mathrm{O}_{4}$ are generated by adding oxidants and promising results are achieved. As such foams are more likely to be stable when they contain small bubbles; see Figure 8, the way to further reduce the particle fraction, reduce costs and facilitate secondary operations and mechanical properties is to simultaneously work on the bubble injection mechanism to reduce bubble size in conjunction with the particle generation method.

This study again shows that the way gas is created in a melt can have a pronounced influence on foam quality. Composites \#4-6 (made by adding Ca metal and oxidising after) can be used to create very uniform foams (socalled Alporas foams) by admixing $\mathrm{TiH}_{2}$ powder but not by injecting gas (see also Ref. [16]). In contrast, $\mathrm{TiB}_{2^{-}}$ containing composites can be foamed in both ways. This could possibly be due to the morphology of the stabilising particles. In composites \#4-6 these particles have complex shapes and often come as very thin but elongated oxide (bi)films [8], whereas $\mathrm{TiB}_{2}$ particles are more compact and near-spherical. Injecting gas through a single injection point requires that stabilising particles can rearrange and adhere to the surface of the injected 
gas bubble that starts rising after detachment from the cannula. Moreover, the rising bubble has to move freely to an empty space between other bubbles. This can cause more problems in melts containing oxide filaments than in melts in which compact particles are embedded. In the former, bubble might be insufficiently stabilised or get caught in unfavourable positions where its potential energy is not minimal. In contrast, a multitude of blowing agent particles creates many bubbles simultaneously in the entire melt volume. The bubbles do not have to travel a long distance and rearrangement of stabilising particles is required just locally around a growing but stationary bubble. Thus, this kind of gas generation leads to stable foams in some composites that are not susceptible to foaming by gas injection.

\section{Conclusions}

Aluminium alloy foams are produced by gas injection into various melts containing different types of in-situ created particles. Foams blown from melts containing $\mathrm{TiB}_{2}$ particles are found to be as stable as foams formed from the well-known composite incorporating $\mathrm{SiC}$ particles (foam heights $>40 \mathrm{~mm}$ are achieved). Aluminium alloy melts conditioned by adding $\mathrm{Ca}, \mathrm{SiO}_{2}$ and $\mathrm{CuO}$ to create oxide particles in-situ can also be foamed but are only partially stable at the present stage of development, with maximum achievable heights below $40 \mathrm{~mm}$. An ultrasonic pre-treatment that degasses a melt and distributes the particles is mandatory in this case. Having $\mathrm{Mg}$ as an alloying element is found to be a prerequisite for stabilisation in all cases.

In summary, it is found that small and well distributed particles created in the melt in combination with reasonably small bubbles $(<4 \mathrm{~mm})$ are a way to reduce the necessary particle fraction. $\mathrm{For} \mathrm{TiB}_{2}(1-3 \mu \mathrm{m}$ particle size), the particle fraction can be reduced to 6 vol.\% compared to the $\geq 10$ vol.\% required for SiC particles (10 $\mu \mathrm{m}$ diameter) if the foams are made under the same conditions. Such a reduction might directly affect production costs, facilitate secondary operations and improve mechanical properties of aluminium alloy foams created by gas injection. 


\section{Compliance with Ethical Standards}

Conflict of Interest: The authors declare that they have no conflict of interest.

\section{Literature}

1. Banhart J, Baumeister J (1998) Porous and cellular materials for structure applications. In: Schwartz DS, Shih DS, Evans AG (eds) Mater. Res. Soc. Symp. San Francisco, pp 121-132.

2. Liu XN, Li YX, Chen X, et al (2010) Foam stability in gas injection foaming process. J Mater Sci 45:6481-6493.

3. Heim K, Vinod-Kumar GS, García-Moreno F, et al (2015) Stabilisation of aluminium foams and films by the joint action of dispersed particles and oxide films. Acta Mater 99:313-324.

4. Jin I, Kenny LD, Sang H (1990) Method of producing a lightweight foamed metal, US Patent.

5. Ip SW, Wang Y, Toguri JM (1999) Aluminium foam stabilization by solid particles. Can Metall Q 38:81-92.

6. Zhou Y, Li Y, Yuan J (2015) The stability of aluminum foams at accumulation and condensation stages in gas injection foaming process. Colloids Surfaces A Physicochem Eng Asp 482:468-476.

7. Leitlmeier D, Degischer HP, Flankl HJ (2002) Development of a foaming process for particulate reinforced aluminum melts. Adv Eng Mater 4:735-740.

8. Babcsán N, Leitlmeier D, Banhart J (2005) Metal foams - High temperature colloids Part I. Ex situ analysis of metal foams. Colloids Surfaces A Physicochem Eng Asp 261:123-130.

9. Kennedy AR, Asavavisithchai S (2004) Effect of ceramic particle additions on foam expansion and stability in compacted Al-TiH2 powder precursors. Adv Eng Mater 6:400-402.

10. Ozben T, Kilickap E, Çakır O (2008) Investigation of mechanical and machinability properties of SiC particle reinforced Al-MMC. J Mater Process Technol 198:220-225.

11. Wang D, Shi Z (2003) Effect of ceramic particles on cell size and wall thickness of aluminum foam. Mater Sci Eng A 361:45-49.

12. Vinod-Kumar GS, Chakraborty M, García-Moreno F, Banhart J (2011) Foamability of MgAl2O4 (spinel)-reinforced aluminum alloy composites. Metall Mater Trans A 42:2898-2908.

13. N. Babcsán, Vinod-Kumar GS, Murty BS, Banhart J (2007) Grain refiners as liquid metal foam stabilisers. Trans Indian Inst Met 60:127-132.

14. Miyoshi T, Itoh M, Akiyama S, Kitahara A (2000) ALPORAS Aluminum foam: production process, properties, and applications. Adv Eng Mater 2:179-183.

15. Atturan UA, Nandam SH, Murty BS, Sankaran S (2016) Processing and characterization of in-situ TiB2 stabilized closed cell aluminium alloy composite foams. Mater Des 101:245-253.

16. Babcsán N, García-Moreno F, Banhart J (2007) Metal foams - High temperature colloids Part II: In situ analysis of metal foams. Colloids Surfaces A Physicochem Eng Asp 309:254-263. 
17. García-Moreno F, Siegel B, Heim K, et al (2015) Sub-mm sized bubbles injected into metallic melts. Colloids Surfaces A Physicochem Eng Asp 473:60-67.

18. García Moreno F, Fromme M, Banhart J (2004) Real-time X-ray radioscopy on metallic foams using a compact micro-focus source. Adv Eng Mater 6:416-420.

19. Bartels C, Raabe D, Gottstein G, Huber U (1997) Investigation of the precipitation kinetics in an Al6061/TiB2 metal matrix composite. Mater Sci Eng 237:12-23.

20. Kellie J, Wood J (1995) Reaction processing in the metals industry. Mater Process 3:10-12.

21. Gergely V, Degischer HP, Clyne TW (2000) Recycling of MMCs and Production of Metallic Foams. In: Compr. Compos. Mater. pp 797-820.

22. Rohatgi PK, Pai BC, Panda SC (1979) Preparation of cast aluminium-silica particulate composites. J Mater Sci 14:2277-2283.

23. Hashim J, Looney L, Hashmi MS. (1999) Metal matrix composites: production by the stir casting method. J Mater Process Technol 92-93:1-7.

24. Xu H, Jian X, Meek TT, Han Q (2004) Degassing of molten aluminum A356 alloy using ultrasonic vibration. Mater Lett 58:3669-3673.

25. Maity PC, Chakraborty PN, Panigrahi SC (1996) Formation of spinel (MgAl2O4), MgO and pure Cu particles in Al-2Mg alloy-CuO particle composites. J Mater Sci 31:6377-6382.

26. Sreekumar VM, Ravi KR, Pillai RM, et al (2008) Thermodynamics and kinetics of the formation of Al2O3/ MgAl2O4/MgO in Al-Silica metal matrix composite. Metall Mater Trans A 39:919-933.

27. Mcleod AD, Gabryel CM (1992) Kinetics of the growth of spinel, MgAI204, on alumina particulate in aluminum alloys containing magnesium. Metall Trans A 23A:1279-1283.

28. Yoshikawa N, Kikuchi A, Taniguchi S (2000) Microstructures of Al/Al2O3 composite bodies obtained by reaction between $\mathrm{SiO} 2$ and molten $\mathrm{Al}$ at temperatures ranging from 1073 to $1473 \mathrm{~K}$. Mater Trans 41:399-405.

29. Babcsán N, Leitlmeier D, Degischer HP, Banhart J (2004) The role of oxidation in blowing particlestabilised aluminium foams. Adv Eng Mater 6:421-428.

30. Vinod-Kumar GS, García-Moreno F, Babcsán N, et al (2007) Study on aluminium-based single films. Phys Chem Chem Phys 9:6415-25.

31. DebRoy T, Bandopadhyay A, Roy R (1994) Oxide matrix composite by directional oxidation of a commercial aluminum-magnesium alloy. J Am Ceram Soc 77:1296-1300.

32. Kaptay G (2004) Interfacial criteria for stabilization of liquid foams by solid particles. Colloids Surfaces A Physicochem Eng Asp 230:67-80.

33. Heim K, Vinod-Kumar GS, García-Moreno F, Banhart J (2014) Role of ambient oxygen in the stabilisation of single aluminium alloy films. Procedia Mater Sci 4:251-256. 


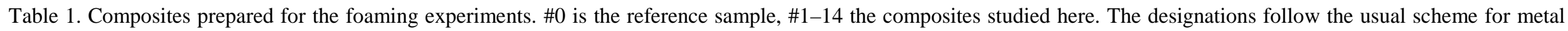
matrix composites for \#0-3 while for the other composites the reactant and its content are given instead of the particle formed in the reaction (therefore marked by an asterisk).

\begin{tabular}{|c|c|c|c|c|c|c|}
\hline \# & $\begin{array}{l}\text { composite designation } \\
\text { (alloy/particles or } \\
\text { *reactants/vol.\%_holding time) }\end{array}$ & Al alloy & reactants & $\begin{array}{l}\text { holding time at } \\
700{ }^{\circ} \mathrm{C}(\mathrm{h})\end{array}$ & $\begin{array}{l}\text { particle or reactand } \\
\text { fraction (vol. \%) }\end{array}$ & reactant size $(\mu \mathrm{m})$ \\
\hline 0 & AlSi9Mg0.6/SiC/20p & AlSi9Mg0.6 & - & - & 20 & - \\
\hline 1 & $\mathrm{Al} / \mathrm{TiB}_{2} / 6 \mathrm{p}$ & Al99.5 & & & & \\
\hline 2 & $\mathrm{AlSi} 9 / \mathrm{TiB}_{2} / 6 \mathrm{p}$ & AlSi9 & $\mathrm{KBF}_{4}$ and $\mathrm{K}_{2} \mathrm{TiF}_{6}$ & 1 & 6 & $50-60 \mu \mathrm{m}$ \\
\hline 3 & AlSi9Mg0.6/TiB $2 / 6 p$ & AlSi9Mg0.6 & & & & \\
\hline 4 & $\mathrm{Al} / * \mathrm{Ca} / 1.5 \mathrm{p}$ & Al99.5 & $\mathrm{Ca}$ & 0.25 & 1.5 & $200-3000$ \\
\hline 5 & $\mathrm{AlSi} /{ }^{*} \mathrm{Ca} / 1.5 \mathrm{p}$ & AlSi9 & $\mathrm{Ca}$ & 0.25 & 1.5 & $200-3000$ \\
\hline 6 & AlSi9Mg0.6/*Ca/1.5p & AlSi9Mg0.6 & $\mathrm{Ca}$ & 0.25 & 1.5 & $200-3000$ \\
\hline 7 & AlSi9Mg0.6/*CuO/1.25p_1h & & & & 1.25 & \\
\hline 8 & AlSi9Mg0.6/*CuO/2.5p_1h & AlSi9Mg0.6 & $\mathrm{CuO}$ & 1 & 2.5 & $<10$ \\
\hline 9 & AlSi9Mg0.6/*CuO/3.75p_1h & & & & 3.75 & \\
\hline 10 & AlSi9Mg0.6/* $\mathrm{SiO}_{2} / 2.5 \mathrm{p} \_1 \mathrm{~h}$ & & & 1 & 2.5 & \\
\hline 11 & AlSi9Mg0.6/*SiO $2 / 2.5 p \_10 h$ & & & 10 & 2.5 & \\
\hline 12 & AlSi9Mg0.6/*SiO $2 / 5 p \_1 h$ & AlSi9Mg0.6 & $\mathrm{SiO}_{2}$ & 1 & 5 & $<50$ \\
\hline 13 & AlSi9Mg0.6/*SiO2/5p_10h & & & 10 & 10 & \\
\hline 14 & AlSi9Mg0.6/*SiO $2 / 10$ p_10h & & & 10 & 10 & \\
\hline
\end{tabular}


Table 2. Summary of the results of the foaming experiments on various composites.

\begin{tabular}{|c|c|c|c|c|c|}
\hline$\#$ & Composite designation & $\begin{array}{c}\text { particle type as } \\
\text { determined by EDX }\end{array}$ & $\begin{array}{c}\text { particle size in } \\
\mu \mathrm{m}\end{array}$ & $\begin{array}{c}\text { foam density } \\
\rho_{\text {foam }} \\
\end{array}$ & $\begin{array}{c}\text { foaming quality } \\
\text { ( } Q \text { given for partially stable foams) }\end{array}$ \\
\hline 0 & AlSi9Mg0.6/SiC/20p & $\mathrm{SiC}$ & 10 & 0.26 & foamable \\
\hline 1 & $\mathrm{Al} / \mathrm{TiB}_{2} / 6 \mathrm{p}$ & \multirow{3}{*}{$\mathrm{TiB}_{2}$} & \multirow{3}{*}{$\begin{array}{c}1-3 \\
* 10-20\end{array}$} & n.a. & not foamable \\
\hline 2 & $\mathrm{AlSi} 9 / \mathrm{TiB}_{2} / 6 \mathrm{p}$ & & & n.a. & not foamable \\
\hline 3 & AlSi9Mg0.6/TiB $2 / 6 p$ & & & 0.32 & foamable \\
\hline 4 & $\mathrm{Al} /{ }^{*} \mathrm{Ca} / 1.5 \mathrm{p}$ & - & n.a. & n.a. & not foamable \\
\hline 5 & $\mathrm{AlSi9} / * \mathrm{Ca} / 1.5 \mathrm{p}$ & - & n.a. & n.a. & not foamable \\
\hline 6 & AlSi9Mg0.6/*Ca/1.5p & - & n.a. & 0.25 & partially foamable (35) \\
\hline 7 & AlSi9Mg0.6/*CuO/1.25p_1h & \multirow{4}{*}{$\begin{array}{c}\mathrm{CuO} * \\
\mathrm{Al}_{2} \mathrm{O}_{3} \\
\mathrm{MgAl}_{2} \mathrm{O}_{4}\end{array}$} & n.a. & n.a. & not foamable \\
\hline 8 & AlSi9Mg0.6/*CuO/2.5p_1h & & \multirow{3}{*}{$\begin{array}{c}0.5-2 \\
* 2-5\end{array}$} & 0.12 & partially foamable (37) \\
\hline 9 & AlSi9Mg0.6/*CuO/3.75p_1h & & & 0.17 & partially foamable (31) \\
\hline 9 & AlSi9Mg0.6/*CuO/3.75p_1h* & & & 0.30 & partially foamable (196) \\
\hline 10 & 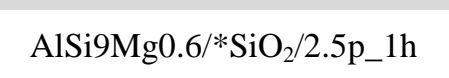 & \multirow{6}{*}{$\begin{array}{c}\mathrm{SiO}_{2} * \\
\mathrm{Al}_{2} \mathrm{O}_{3} \\
\mathrm{MgAl}_{2} \mathrm{O}_{4}\end{array}$} & n.a. & 0.12 & not foamable \\
\hline 11 & AlSi9Mg0.6/*SiO $/ 2.5 p \_10 h$ & & n.a. & 0.11 & not foamable \\
\hline 12 & AlSi9Mg0.6/*SiO $/ 5 p \_1 h$ & & \multirow{4}{*}{$\begin{array}{c}1-2 \\
* 5-10\end{array}$} & 0.13 & partially foamable (27) \\
\hline 12 & 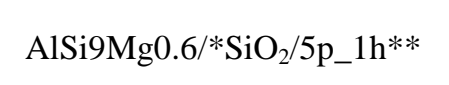 & & & 0.18 & partially foamable (76) \\
\hline 13 & AlSi9Mg0.6/*SiO $2 / 5 p \_10 h$ & & & 0.11 & partially foamable (54) \\
\hline 14 & 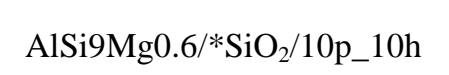 & & & 0.21 & partially foamable (30) \\
\hline
\end{tabular}


Table 3. EDX bulk elemental analysis of the samples shown in Figure 9 and Figure 10 at the numbered positions. All elemental values are given in wt.\%.

\begin{tabular}{cccccccc} 
composite & No. & Al & Mg & Si & O & Cu & Al/Mg \\
\hline AlSi9Mg0.6/*CuO/2.5p_1h & 1 & 6.00 & - & 7.48 & 28.07 & 45.12 & $\infty$ \\
$(\# 8)$ & 2 & 9.42 & 3.84 & 16.01 & 44.28 & 10.30 & 2.45 \\
& 3 & 13.12 & 5.29 & 13.61 & 30.71 & 25.66 & 2.48 \\
AlSi9Mg0.6/* $\mathrm{SiO}_{2} / 5 \mathrm{p} \_1 \mathrm{~h}$ & 1 & 44.17 & 13.76 & 0.78 & 40.45 & - & 3.21 \\
$(\# 12)$ & 2 & 21.54 & 1.88 & 56.83 & 18.16 & - & 11.45 \\
\hline
\end{tabular}




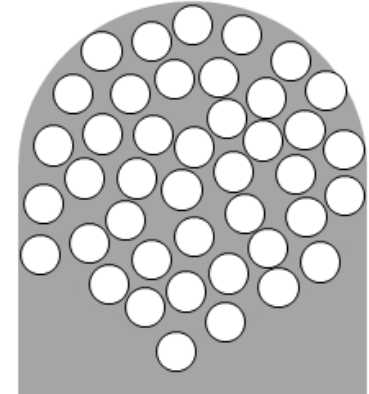

a)
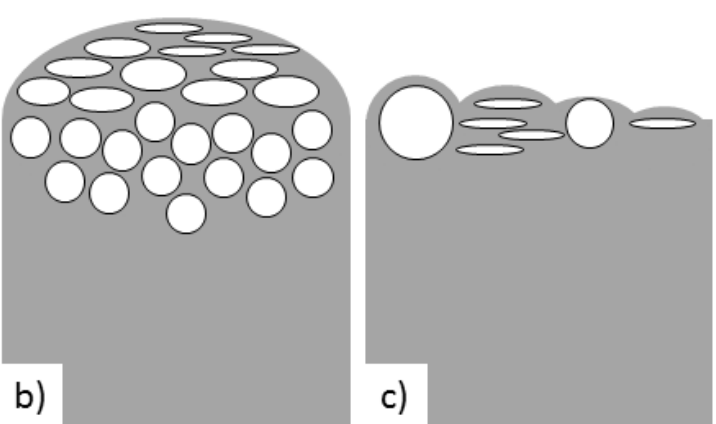

Figure 1. Schematic of the three levels of foamability of a melt as defined in this paper: a) foamable, b) partially foamable and c) not foamable. 


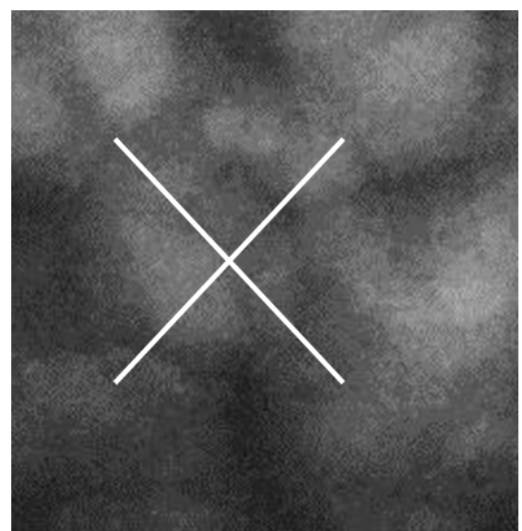

a)

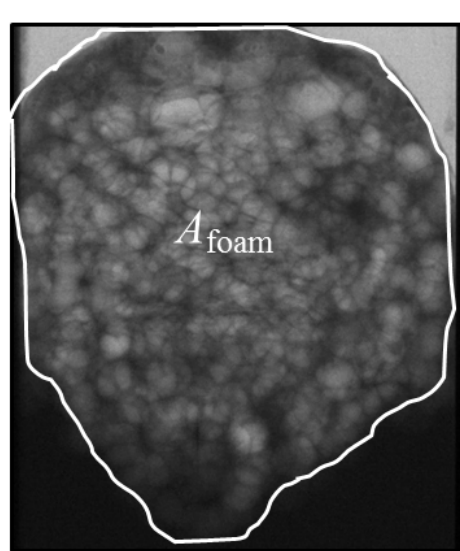

b)

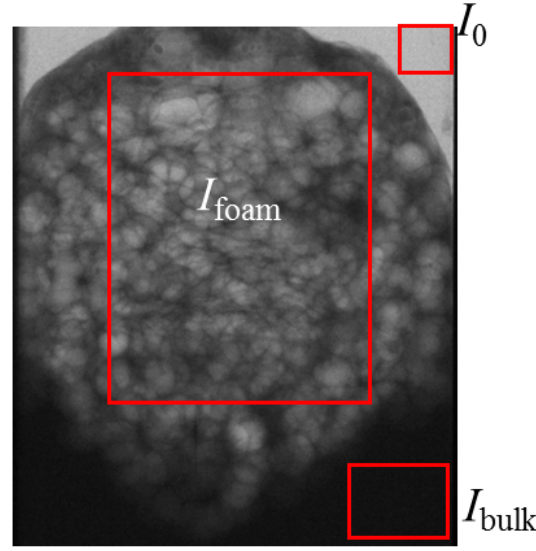

c)
$10 \mathrm{~mm}$

Figure 2. Visualisation of how values for the evaluation of foam quality using Eqs. (11) and (12) are determined. a) line intersection method based on two perpendicular lines to determine $A_{\text {bubble, }}$ b) definition of foam area $A_{\text {foam }}$ and c) areas selected to measure the averaged transmitted X-ray intensities $I_{\text {foam }}, I_{\text {bulk }}$ and $I_{0}$. The foam displayed is made of AlSi9Mg0.6/*CuO/3.75p (\#9) composite and is kept liquid for $60 \mathrm{~s}$ after gas injection has been stopped. The foaming temperature is $680^{\circ} \mathrm{C}$ and the smaller cannula $\left(d_{o}=200 \mu \mathrm{m}\right)$ is used. 


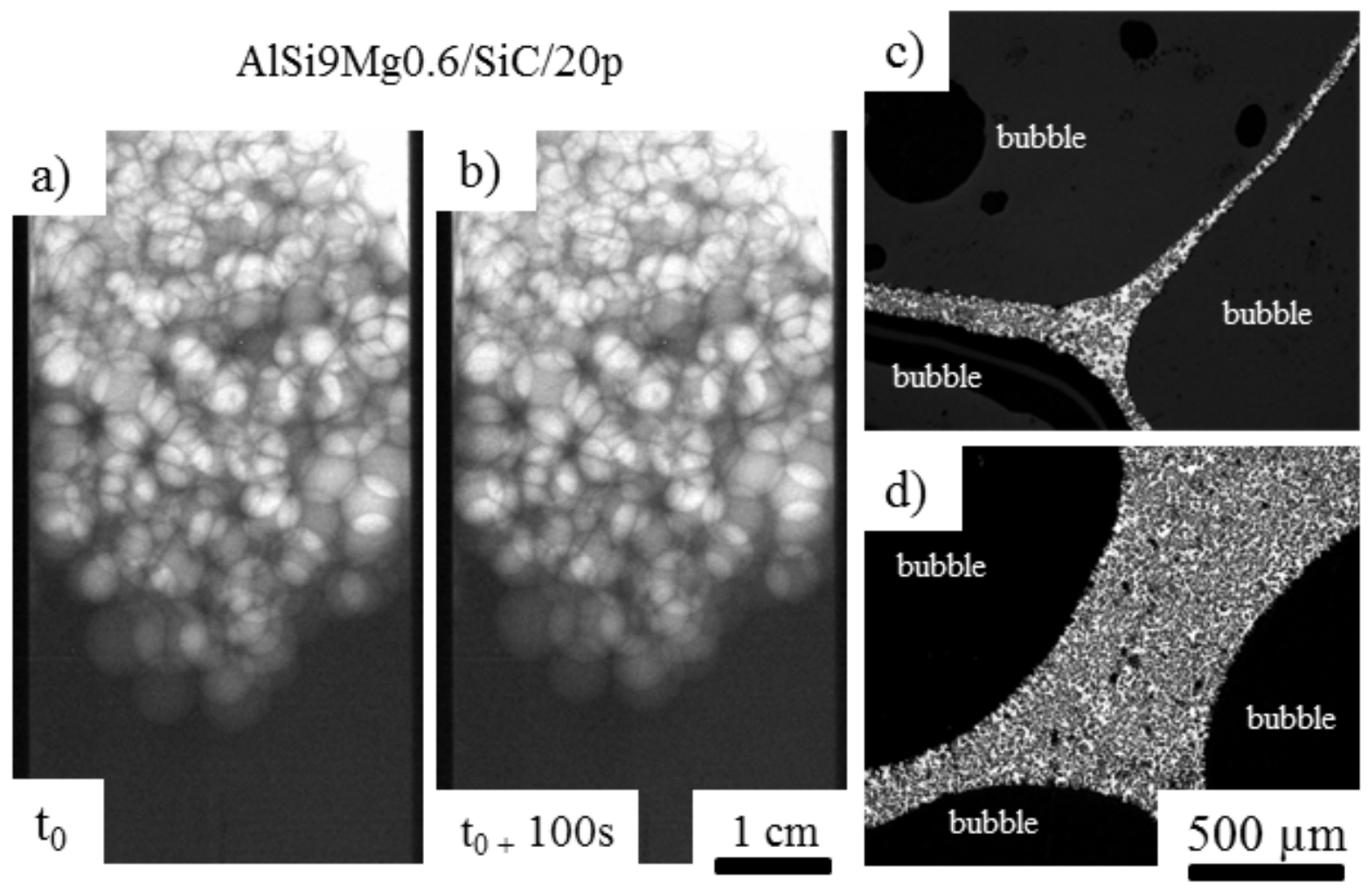

Figure 3. a,b) X-ray radioscopies of liquid AlSi9Mg0.6/SiC/20p (\#0) foam after $15 \mathrm{~s}$ of gas injection $\left(t_{0}\right)$ and after further $100 \mathrm{~s}$ of holding at $680^{\circ} \mathrm{C}$. Bubble blowing was through an injection cannula of diameter $d_{o}=$ $500 \mu \mathrm{m}$. Corresponding metallographic cross sections of films and Plateau borders taken from the c) top and d) bottom of the solidified foam. SiC particles are black, the matrix white. 


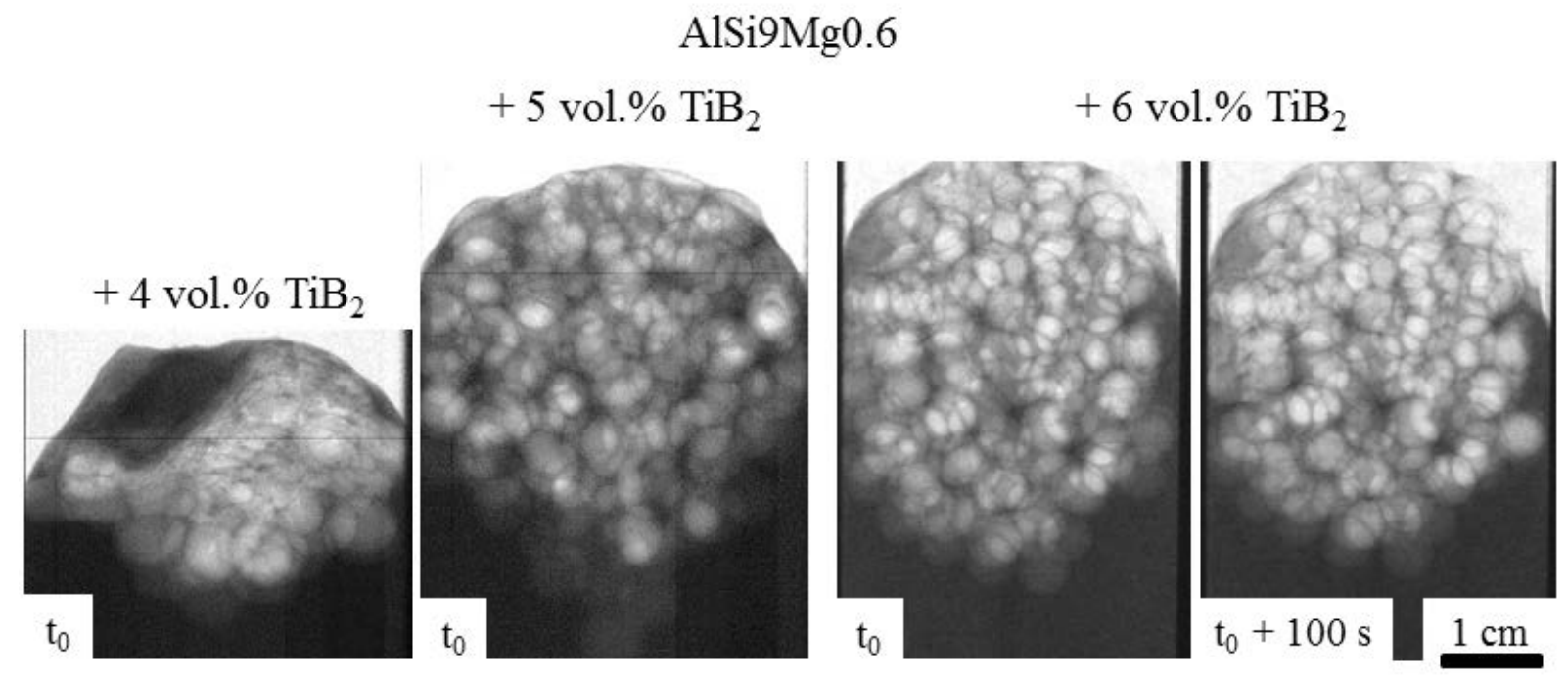

Figure 4. X-ray radioscopies of liquid a) $\mathrm{Al} / \mathrm{TiB}_{2} / 6 \mathrm{p}$ (\#1), b) $\mathrm{AlSi} 9 / \mathrm{TiB}_{2} / 6 \mathrm{p}$ (\#2) foam after $15 \mathrm{~s}$ of gas injection. c) AlSi9Mg0.6/TiB $/ 6 \mathrm{p}(\# 3)$ after $15 \mathrm{~s}$ of injection $\left(\mathrm{t}_{0}\right)$ and d) after further $100 \mathrm{~s}$ of holding at $680{ }^{\circ} \mathrm{C}$. Bubbles were blown with an injection cannula of $d_{0}=500 \mu \mathrm{m}$ diameter. 

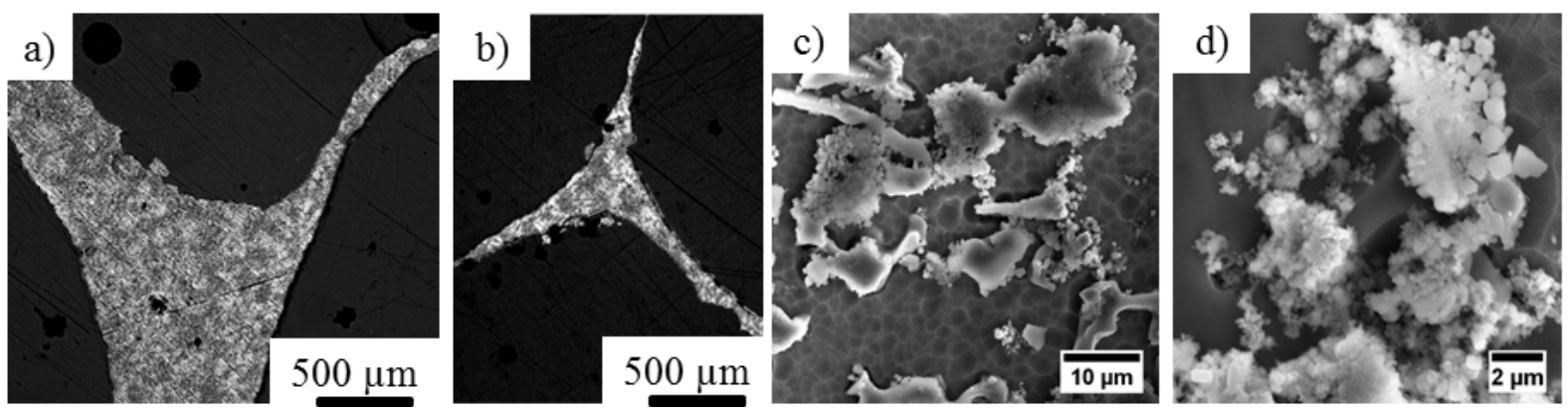

Figure 5. Metallographic cross sections of an AlSi9Mg0.6/TiB $/ 6$ p (\#3) Plateau border taken from a) the bottom and b) top of the foam. c) and d) SEM images of a) and b), respectively, at different magnifications using an inlens detector. $\mathrm{TiB}_{2}$ particles are bright, $\mathrm{Al}$ matrix is dark. 

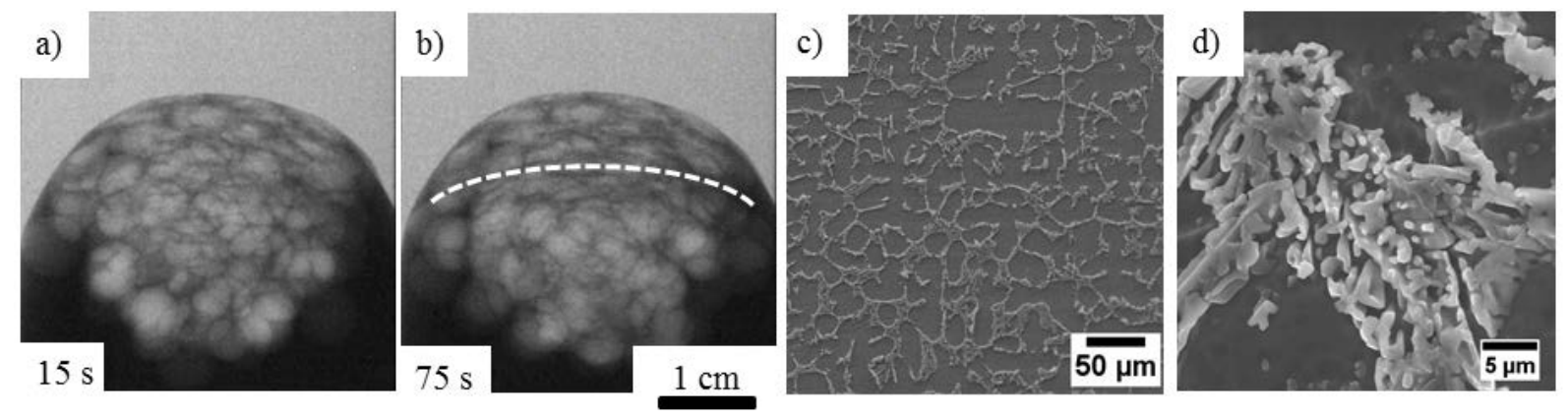

Figure 6. X-ray radioscopies of liquid AlSi9Mg0.6/*Ca/1.5p (\#6) foam created using an injection cannula of $d_{0}=$ $500 \mu \mathrm{m}$ diameter after a) $15 \mathrm{~s}$ and b) $75 \mathrm{~s}$ of continuous injection at $680^{\circ} \mathrm{C}$ foaming temperature. The white dashed line delimits the area of collapsed bubbles. c,d) SEM images taken at different magnifications using an in-lens detector. Si appears bright, the $\mathrm{Al}$ matrix dark. 


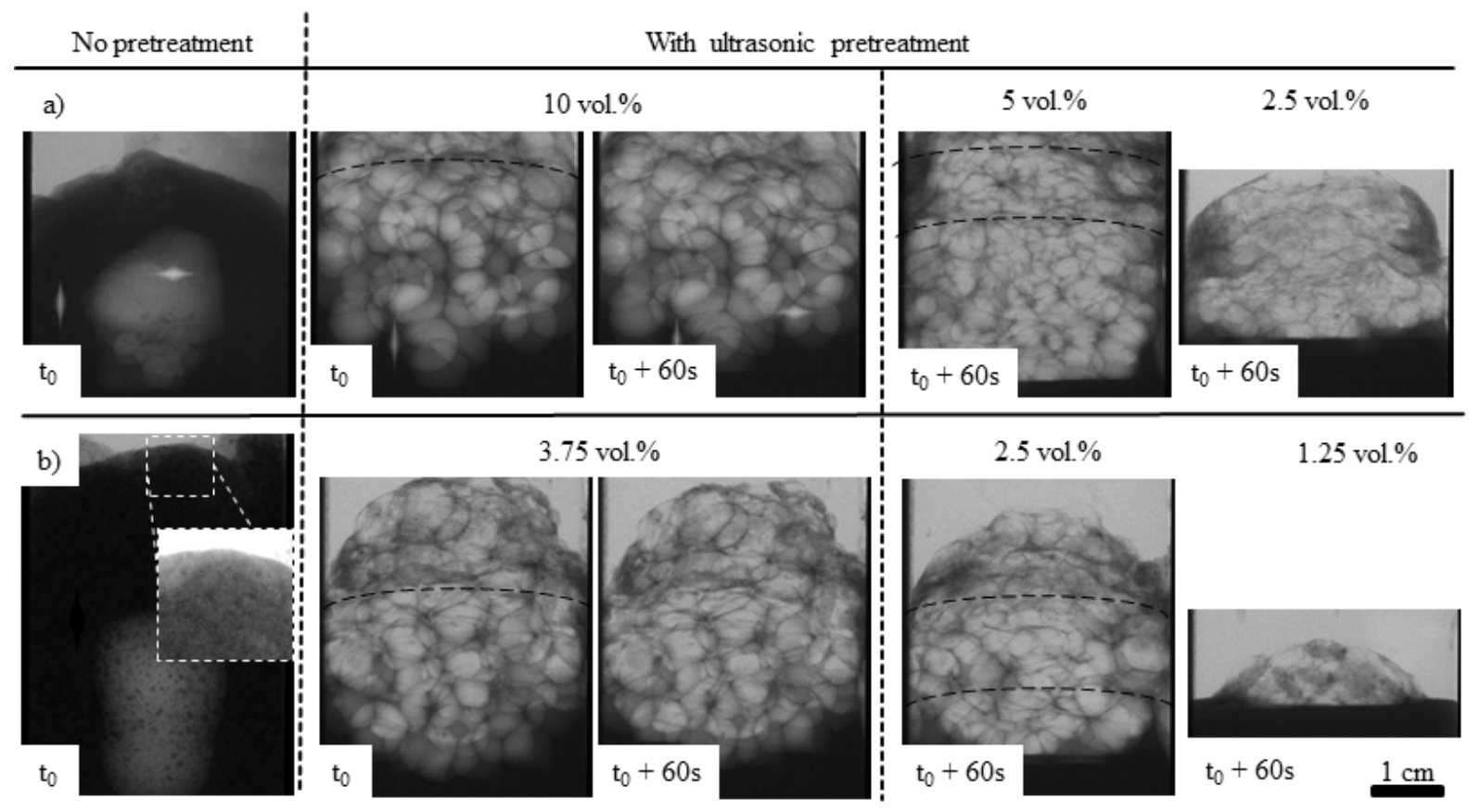

Figure 7. X-ray radioscopies of foams made at $680^{\circ} \mathrm{C}$ from untreated and ultrasonically pre-treated samples of AlSi9Mg0.6 containing different amounts of a) $\mathrm{SiO}_{2}(10 \mathrm{~h}$ reaction time, \#11,13,14) and b) $\mathrm{CuO}(1 \mathrm{~h}$ reaction time, \#7,8,9). The white dashed lines delimit the area of collapsed bubbles. Images are taken after gas injection had stopped $\left(t_{0}\right)$ or after additional $60 \mathrm{~s}$ of holding $\left(t_{0}+60 \mathrm{~s}\right)$. The injection cannula with $d_{0}=500 \mu \mathrm{m}$ is used. The inset in b) shows the top layer of small bubbles caused by poorly wetted particles during mixing. 

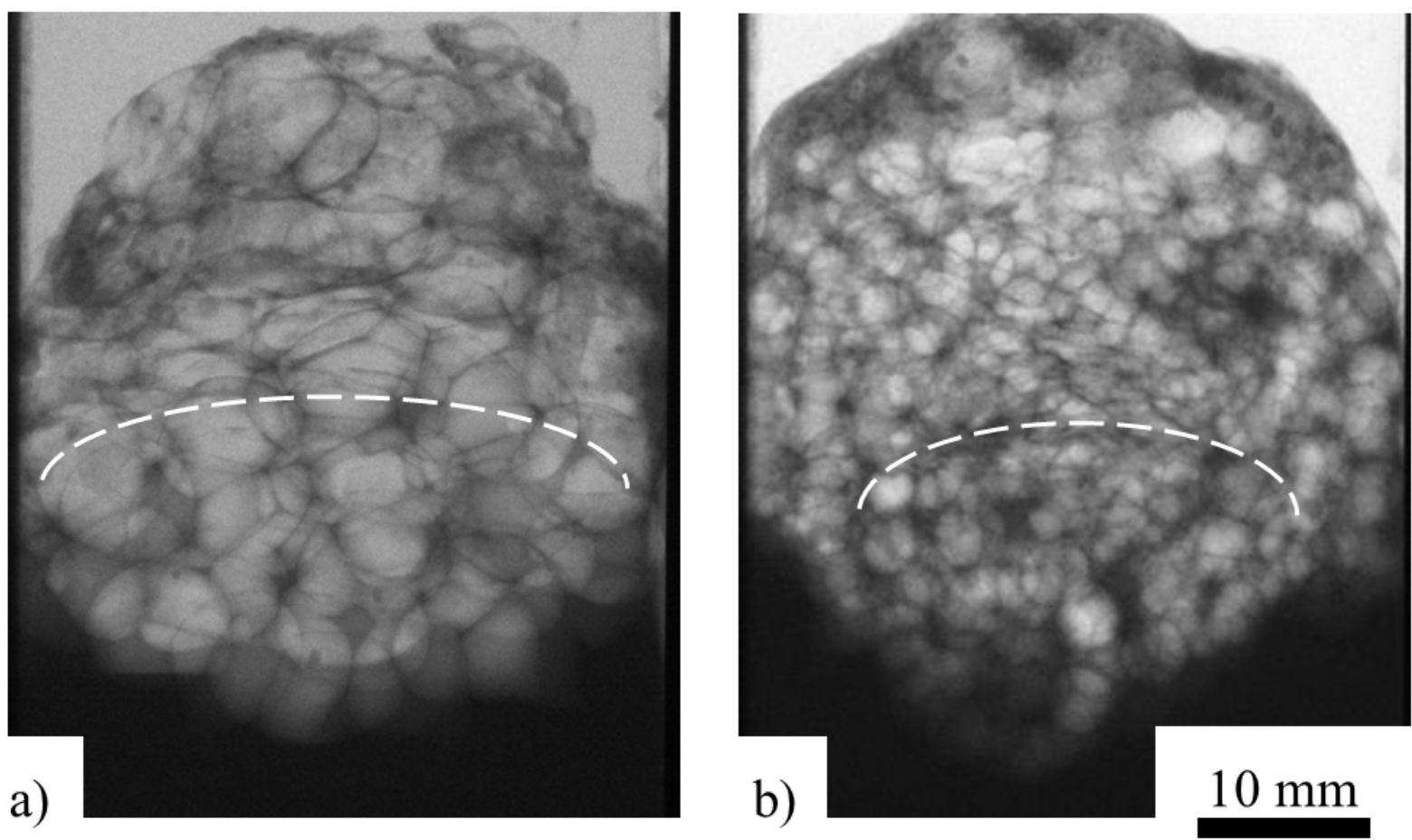

Figure 8. X-ray radioscopies of ultrasonically pre-treated AlSi9Mg0.6/*CuO/3.75p melt (\#9) after gas injection has stopped and the foam is kept liquid for another $60 \mathrm{~s}$ at $680^{\circ} \mathrm{C}$. The white dashed lines delimit the area of collapsed bubbles. Two injection cannula diameters are used, $d_{0}=$ a) $500 \mu \mathrm{m}$, b) $200 \mu \mathrm{m}$. 

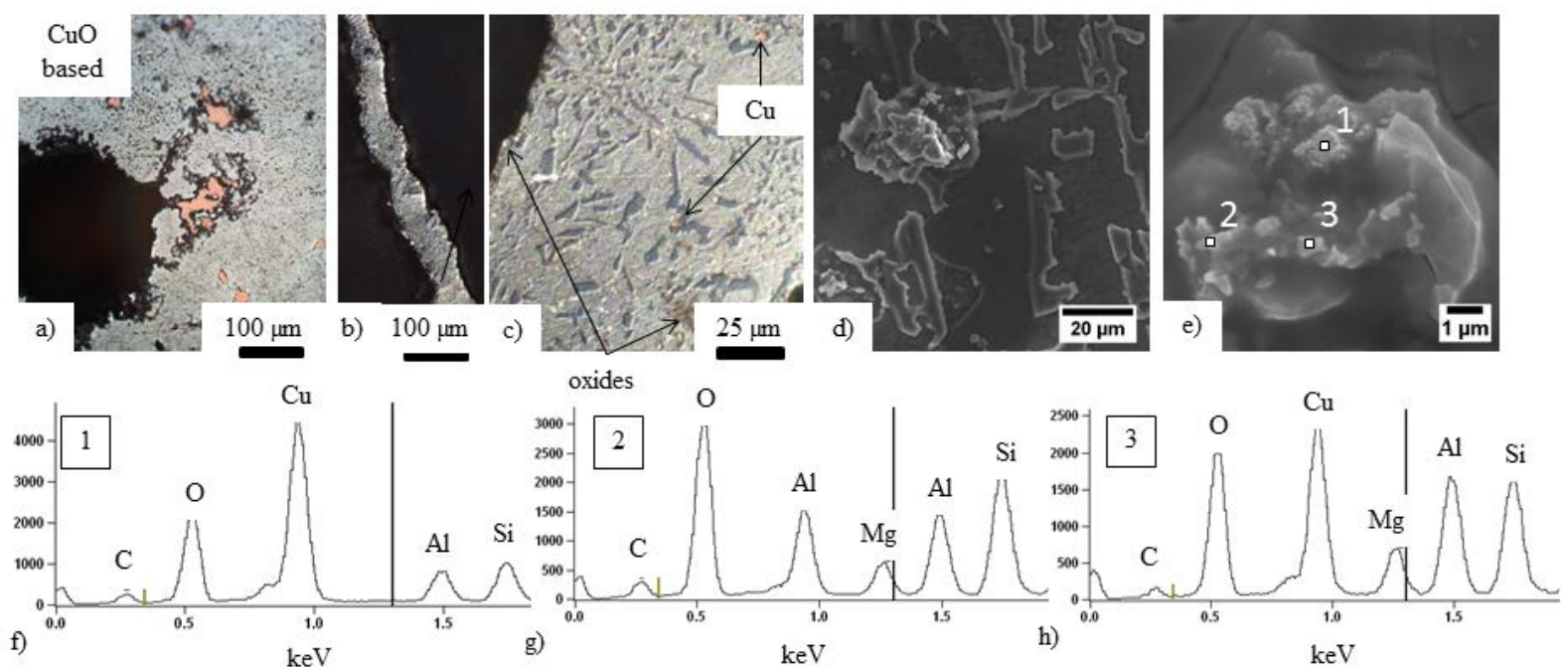

Figure 9. Optical micrographs of a) untreated bulk AlSi9Mg0.6/*CuO/2.5p (\#8) and b, c) stable films in foams made from ultrasonically pre-treated composite (also shown in Figure 6). $\mathrm{Al}$ matrix is white, Si dark grey, $\mathrm{CuAl}_{2}$ reddish and reacted oxides black. d,e) SEM images taken at different magnifications using an in-lens detector. Blocky areas in d) are Si, particles in e) are oxides and oxidant remnants of various composition. $\mathrm{f}-\mathrm{h}$ ) Corresponding EDX spectra are given below. 

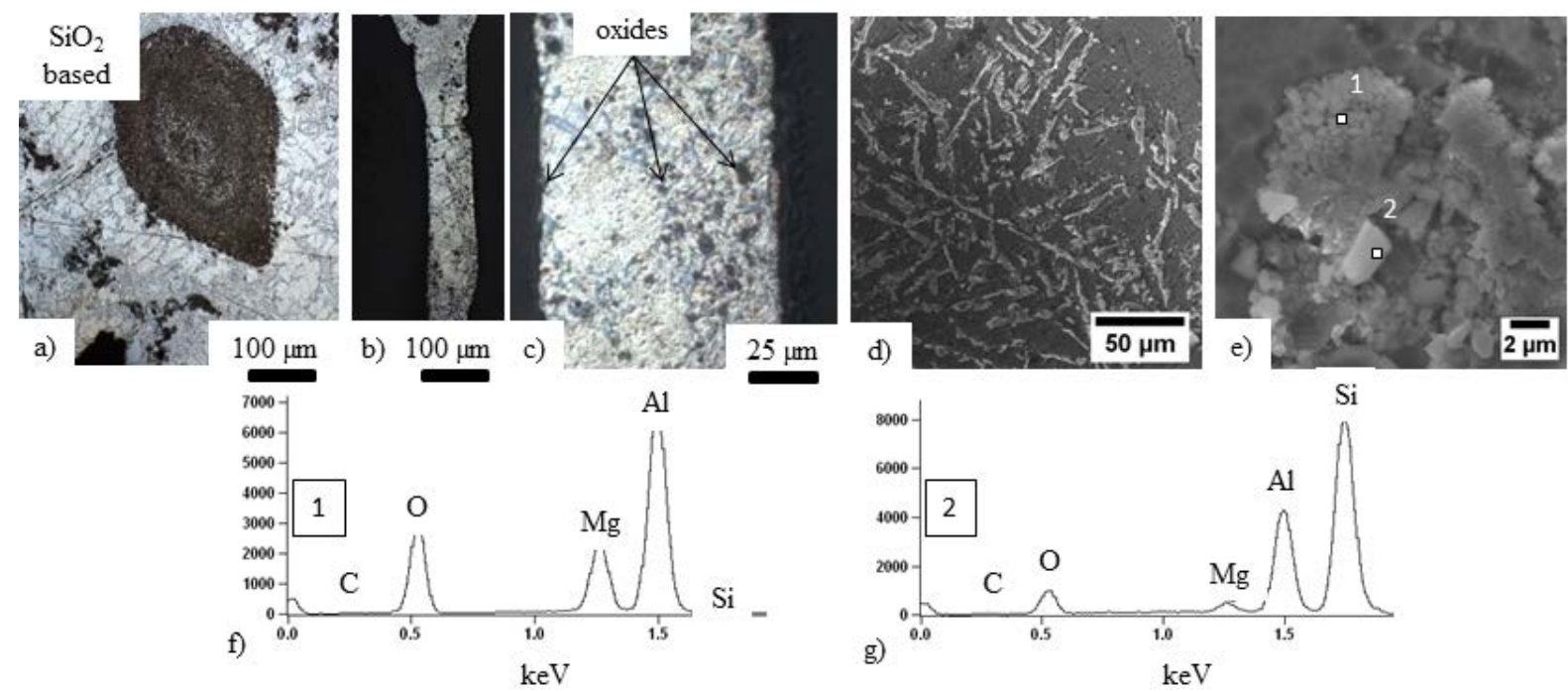

Figure 10. Same as Figure 8 for AlSi9Mg0.6/SiO $/ 5 p$ (\#12). In b,c) Al matrix is white, Si dark grey, and reacted oxides black. d,e) SEM images taken at different magnifications using an in-lens detector. Blocky areas in d) are $\mathrm{Si}$, particles in e) are oxides and oxidant remnants of various composition. f,g) Corresponding EDX spectra are given below. 


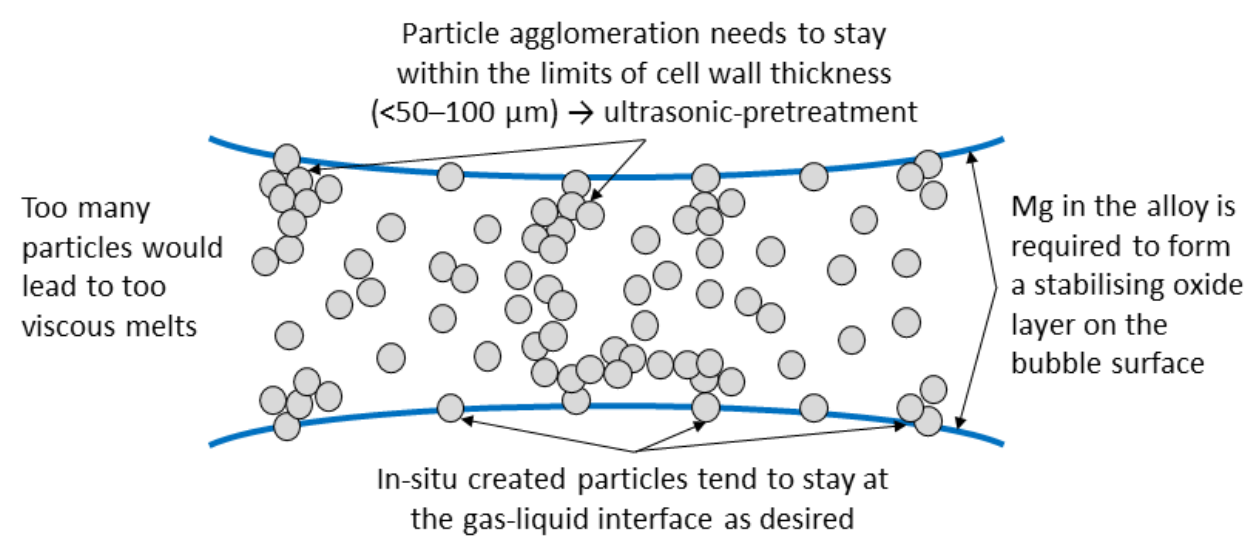

Figure 11. Summary of requirements determining whether a metal-particle composite can be converted to a stable foam by gas injection. A schematic cross-section of a film in a liquid foam and the arrangement of particles within is shown. 